\title{
PENGARUH LAYANAN KONSELING KELOMPOK TERHADAP KEJENUHAN BELAJAR SISWA
}

Oleh:

\author{
Ridha Yana Magrur'), Nani Restati Siregar ${ }^{2)}$, Dodi Priyatmo Silondae ${ }^{3)}$ \\ 1) 2) 3) Jurusan Bimbingan dan Konseling \\ Fakultas Keguruan dan Ilmu Pendidikan, Universitas Halu Oleo \\ Email: ridhaynm@gmail.com
}

\begin{abstract}
ABSTRAK
Penelitian ini bertujuan untuk mengetahui adanya pengaruh layanan konseling kelompok terhadap kejenuhan belajar siswa di SMK Negeri 1 Kendari. Jenis Metode ini adalah penelitian Pre Eksperimen dengan desain One Group Pre Test and Post Test. Subjek dalam penelitian ini berjumlah 8 orang siswa. Data dikumpulkan dengan menggunakan angket skala kejenuhan belajar siswa. Berdasarkan data hasil analisis deskriptif persentase menunjukkan bahwa kejenuhan belajar siswa sebelum diberikan perlakuan berupa layanan konseling kelompok rata-rata skor pre test siswa yaitu $74,11 \%$ berada pada kategori tinggi. Sesudah diberikan perlakuan rata-rata skor post test mengalami penurunan sebesar 48,82\% berada pada kategori rendah. Secara seluruhan penurunan skor kejenuhan belajar sebesar 25,29\%. Berdasarkan hasil analisis inferensial menggunakan Wilcoxon signed rank pada taraf signifikan $\alpha=0,05$ diperoleh $P_{\text {value }}=0,012$. $P_{\text {value }}<\alpha(0,012$ $<0,05)$ dengan demikian $H_{a}$ diterima. Maka dapat disimpulkan bahwa layanan konseling kelompok dapat mengurangi kejenuhan belajar siswa di SMK Negeri 1 Kendari.
\end{abstract}

Kata Kunci: Konseling Kelompok, Kejenuhan Belajar Siswa

\section{THE EFFECT OF GROUP COUNSELING SERVICE ON STUDENTS BOREDOM TO LEARNING}

\begin{abstract}
The purpose of the research was to find out the effect of group counseling service on students boredom to learning in SMK Negeri 1 Kendari. The method of the study was pre-experimental research with One Group Pre Test and Post Test design. The subjects of the study were 8 students. The subjects were determined by the higher of the pre test results. The data were collected through questionnaires on students boredom to learning. Based on the result of percentage descriptive analysis shows that before the students have been provided with group counseling service, the students boredom to learning were in high category, their pre test average score was $75.11 \%$. After the students have been provided with group counseling service, the students boredom to learning are decreasing into low category. Their average post test score was $48.82 \%$. Based on the result of inferential analyses using Wilcoxon signed rank test, it was found that it's significant was $a=0,050$ with its Pvalue $=0.012$. Pvalue $<a(0.012<0.05)$. The test result indicates that Hais accepted. It can therefore be concluded that group counseling service is able to reduce the students boredom to learning in SMK Negeri 1 Kendari.
\end{abstract}

Keywords: Group Counseling, Students Boredom to Learning. 


\section{Pendahuluan}

Belajar merupakan suatu proses usaha yang dilakukan seseorang untuk memeroleh suatu perubahan tingkah laku yang baru secara keseluruhan, sebagai hasil pengalamannya sendiri dalam interaksi dengan lingkungannya. Sebagai aktifitas yang dinamis belajar dapat mengembangkan kreativitas berfikir dan meningkatkan pengetahuan dan keterampilan siswa secara utuh. Guna memeroleh hasil belajar yang baik dibuntuhkan konsentrasi dan atau adanya kesiapan secara fisik dan psikologis agar belajar menjadi menyenangkan dan tidak menimbulkan stres.

Jika stres dialami siswa maka dapat berpengaruh pada fisik dan aspek psikologisnya yang akan mengakibatkan terganggunya proses belajar. Stres yang tidak dapat dikelola secara baik dapat menyebabkan kejenuhan. Slivar (dalam Kurniawan, 2016) menyatakan bahwa stres yang berkepanjangan akan menyebabkan seseorang mengalami kejenuhan saat belajar. Secara harfiah kejenuhan ialah padat atau penuh sehingga tidak mampu memuat apapun.

Rebet (dalam syah 2015: 181) mengemukakan bahwa kejenuhan belajar merupakan lama waktu yang digunakan pada saat anak-anak sedang belajar, tetapi tidak mendatangkan hasil yang dicapai. Siswa yang mengalami kejenuhan belajar membuat proses belajarnya menjadi terganggu karena siswa tidak dapat berpikir dan memahami segala macam pengetahuan yang diperoleh dari belajarnya dengan baik sehingga tidak ada kemajuan.

Berdasarkan survei awal yang dilakukan pada siswa kelas XI Pemasaran 3 (tiga) SMK Negeri 1 Kendari diketahui permasalahan belajar yang sering dialami sebagian siswa adalah ketidakmampuan dalam mengoptimalkan kegiatan belajar karena adanya keletihan yang dialami ketika jam belajar berlangsung, selalu menghindari kegiatan belajar dan kurangnya motivasi yang timbul untuk melakasanakan proses pembelajaran di sekolah.

Permasalahan tersebut didasari pada hasil wawancara peneliti dengan guru Bimbingan dan Konseling (BK) di SMK Negeri 1 Kendari, hasil wawancara tersebut menunjukkan bahwa terdapat beberapa siswa yang sering terindikasi mengalami kejenuhan belajar. Masalah ini timbul karena ketidakpedulian siswa terhadap kegiatan belajar, hilangnya rasa tanggung jawab, emosional siswa yang tidak terkontrol, hilangnya konsentrasi belajar, serta kurangnya motivasi belajar, tidak konsentrasi pada saat pembelajaran, suasana hati yang buruk saat belajar dan pembelajaran yang tidak disukai. Bahkan, tak jarang dari mereka yang bersikap menyimpang seperti membolos.

Berdasarkan gejala-gejala yang terjadi di SMK Negeri 1 Kendari, maka untuk mengurangi siswa yang mengalami kejenuhan belajar bukan hal yang mudah. Sehingga harus ada kerja sama dari diri siswa itu sendiri, keluarga, lingkungan rumah maupun lingkungan sekolah. Pada lingkungan sekolah, guru BK memiliki peran yang penting dalam membantu siswa untuk menyelesaikan permasalahannya.

Kondisi kejenuhan belajar siswa harus segera ditangani, jika tidak dan dibiarkan begitu saja maka kegiatan belajar siswa tidak akan berjalan efektif, mengalami kemunduran dalam hal tercapai tujuan belajar, serta berdampak ke hal yang lebih lanjut yakni, ke jenjang perguruan tinggi. Dibutuhkan penanganan yang lebih tepat, salah satunya melalui layanan bimbingan dan konseling di sekolah. Bimbingan dan konseling merupakan proses yang bersifat membantu siswa dalam mengubah perilaku untuk pencapaian perkembangan pribadi secara optimal. Kejenuhan belajar merupakan masalah dari bidang belajar. Bidang belajar merupakan bagian dari bimbingan dan konseling.

Salah satu yang menjadi komponen bimbingan dan konseling adalah layanan konseling kelompok. Tohirin (2015: 172) mengemukakan bahwa konseling kelompok adalah suatu upaya pembimbing atau konselor membantu memecahkan masalah-masalah pribadi yang dialami oleh masing-masing anggota kelompok melalui kegiatan kelompok agar tercapai perkembangan yang optimal. Dalam konseling kelompok, dinamika harus dapat dikembangkan secara baik, sehingga mendukung pencapaian tujuan layanan secara efektif. Berdasarkan penjelasan tersebut, peneliti berasumsi bahwa layanan konseling kelompok adalah salah satu layanan bimbingan dan konseling yang dapat memengaruhi siswa dalam memecahkan masalahnya terkhusus dalam mengatasi masalah kejenuhan belajar yang dialami siswa.

Subtansinya, melalui kegiatan konseling kelompok, siswa dapat berlatih berbicara, mengembangkan potensi diri, meningkatkan motivasi belajar dan melatih kecakapan dalam mengolah materi pelajaran melalui dinamika kelompok serta aspek-aspek positif lainnya, yang 
pada akhirnya individu dapat mengembangkan potensi diri dan memecahkan masalah secara bersama-sama. Sehingga dengan pemberian layanan konseling kelompok dapat lebih mengembangkan potensi, wawasan, perasaan, pikiran, membentuk sikap dan bertindak sesuai apa yang diharapkan. Dengan adanya konseling kelompok. Maka melalui layanan konseling kelompok siswa diharapkan dapat mengurangi tingkat kejenuhan belajarnya.

Berdasarkan latar belakang tersebut, peneliti tertarik untuk melakukan layanan konseling kelompok dalam sebuah penelitian yang berjudul "Pengaruh Layanan Konseling Kelompok Terhadap Kejenuhan Belajar Siswa SMK Negeri 1 Kendari". Tujuan penelitian ini adalah untuk mengetahui pengaruh pemberian layanan konseling kelompok dalam menurunkan kejenuhan belajar siswa SMK Negeri 1 Kendari.

\section{Kejenuhan Belajar}

Secara harfiah, arti kejenuhan ialah padat atau penuh sehingga tidak mampu lagi memuat apapun. Sedangkan menurut Syah (2015: 161) jenuh dapat berarti jemu dan bosan dimana sistem akalnya tidak dapat bekerja sesuai dengan yang diharapkan dalam memproses item-item informasi atau pengalaman baru.

Menurut Reber (dalam Syah, 2015: 180) kejenuhan belajar adalah rentang waktu tertentu yang digunakan untuk belajar, tetapi tidak mendatangkan hasil. Seorang siswa yang mengalami kejenuhan belajar seakan-akan pengetahuan dan kecakapan yang diperoleh dari belajar tidak ada kemajuannya. Tidak adanya kemajuan hasil belajar ini pada umumnya tidak berlangsung selamanya, tetapi dalam rentang waktu tertentu saja, misalnya seminggu. Namun, tidak sedikit siswa yang mengalami rentang waktu yang membawa kejenuhan itu berkali-kali dalam satu periode belajar tertentu.

Berdasarkan beberapa pendapat tersebut, dapat disimpulkan bahwa kejenuhan belajar adalah kondisi dimana siswa merasa lelah secara fisik dan emosional karena banyaknya tanggung jawab dan tekanan yang berkaitan dengan belajar sehingga tidak bersemangat untuk melakukan aktivitas belajar.

Faktor-faktor yang memengaruhi kejenuhan belajar

Chaplin (dalam Syah, 2015: 181) membagi faktor kejenuhan belajar yang berasal dari luar dan dari dalam. Kejenuhan belajar yang berasal dari luar diri siswa adalah ketika siswa berada pada situasi kompetitif yang ketat dan menuntut kerja intelek yang berat. Selanjutnya, kejenuhan belajar yang berasal dari dalam diri siswa adalah ketika siswa bosan dan keletihan. Keletihan yang dialami oleh siswa dapat menyebabkan kebosanan dan siswa dapat kehilangan motivasi serta malas untuk mengikuti pelajaran yang diajarkan.

Indikator kejenuhan belajar

Sesuai dengan aspek-aspek di atas. Maka dapat diperoleh indikator dari kejenuhan belajar menurut Schaufeli \& Enzmann (Vitasari, 2016: 60) yaitu:

1. Kelelahan emosi: Perasaan depresi,rasa sedih, kelelahan emosional, kemampuan mengendalikan emosi, ketakutan yang tidak berdasar dan kecemasan.

2. Kelelahan fisik: Gejala yang terjadi pada kelelahan fisik adalah seperti sakit kepala, mual, pusing, gelisah, otot-otot sakit, gangguan tidur, masalah seksual, penurunan berat badan, kurangnya nafsu makan, sesak napas, siklus menstruasi yang tidak normal, kelelahan fisik, kelelahan kronis, kelemahan tubuh, tekanan darah tinggi

3. Kelelahan kognitif: Ketidakberdayaan, kehilangan harapan dan makna hidup, ketakutan dirinya menjadi "gila", perasaan tidak berdaya dan dirinya tidak mampu untuk melakukan sesuatu, perasaan gagal yang selalu menghantui, pengahargaan diri yang rendah, munculnya ide bunuh diri, ketidakmampuan untuk berkonsentrasi, lupa, tidak dapat mengerjakan tugas-tugas yang kompleks, kesepian, penurunan daya tahan dalam menghadapi frustasi yang dirasakan.

4. Kehilangan motivasi: kehilangan semangat, kehilangan idealisme, kecewa, pengunduran diri dari lingkungan, kebosanan dan demoralisasi.

\section{Pengertian konseling kelompok}

Konseling kelompok adalah upaya bantuan yang bersifat pencegahan dan pengembangan kemampuan pribadi sebagai pemecahan masalah secara kelompok atau bersama-sama dari seorang konselor kepada klien (Lubis \& Hasnida, 2016: 19). Selanjutnya, Harrisson (dalam Kurnanto, 2013: 7) menjelaskan bahwa konseling kelompok adalah konseling yang terdiri dari 4-8 konseli yang bertemu dengan 1-2 konselor. 
Konseling kelompok dapat membicarakan beberapa masalah seperti kemampuan dalam membangun hubungan dan komunikasi, pengembangan harga diri, dan keterampilanketerampilan dalam mengatasi masalah. Senada dengan utaian di atas Latipun (2017: 128), mengemukakan pengertian konseling kelompok sebagai salah satu bentuk konseling dengan memanfaatkan kelompok untuk membantu, memberi umpan balik (feedback) dan pengalaman belajar. Konseling kelompok dalam prosesnya menggunakan prinsip-prinsip dinamika kelompok (group dynamic).

Berdasarkan beberapa pengertian di atas, dapat diketahui bahwa konseling kelompok adalah upaya bantuan yang diberikan tenaga ahli dengan memanfaatkan dinamika kelompok untuk membantu peserta didik dapat menghadapi dan mengentaskan masalah hidup yang dihadapinya.

Tujuan pelaksanaan konseling kelompok bagi konseli adalah untuk mengembangkan berbagai keterampilan yang pada intinya meningkatkan kepercayaan diri (self confidence) dan kepercayaan terhadap orang lain (Kurnanto, 2013: 12). Selain itu, Krumboltz (dalam Lubis \& Hasnida, 2016: 43) menyebutkan tujuan konseling kelompok terbagi menjadi tiga jenis, yakni sebagai berikut:

1. Mengubah penyesuaian tingkah laku yang salah. Penyesuaian perilaku yang salah adalah perilaku yang secara psikologis mengarah pada perilaku patologis. Penyesuaian perilaku yang salah inilah yang akan dirubah menjadi perilaku yang sehat yang tidak mengandung indikasi adanya hambatan atau kesulitan mental.

2. Belajar membuat keputusan. Belajar membuat keputusan tidak mudah dilakukan oleh klien padahal hal tersebut harus dilakukan sebagai bagian dari tujuan konseling.

3. Mencegah timbulnya masalah. Tujuan konseling adalah mencegah agar masalah tidak menimbulkan hambatan dikemudian hari, mencegah agar masalah yang dihadapi cepat terselesaikan, dan mencegah agar masalah tidak menimbulkan gangguan.

Fungsi layanan konseling kelompok

Nurihsan (dalam Kurnanto, 2013: 9) mengatakan bahwa konseling kelompok bersifat pencegahan dan penyembuhan. Konseling kelompok bersifat pencegahan, dalam arti bahwa individu yang dibantu memunyai kemampuan normal atau berfungsi secara wajar di masyarakat, tetapi memiliki beberapa kelemahan dalam kehidupannya sehingga mengganggu kelancaran berkomunikasi dengan orang lain. Sedangkan konseling kelompok bersifat penyembuhan dalam pengertian membantu individu untuk dapat keluar dari persoalan yaang dialaminya dengan cara memberikan kesempatan, dorongan, juga pengarahan kepada individu untuk mengubah sikap dan perilakunya agar selaras dengan lingkungannya. .

Melengkapi dengan penjelasan di atas, Adhiputra (dalam Lubis \& Hasnida, 2016: 42) juga menyebutkan bahwa secara konseptual konseling kelompok merupakan upaya bantuan kepada individu dalam suasana kelompok yang bersifat pencegahan dan pengembangan, dan diarahkan kepada pemberian kemudahan dalam rangka pertumbuhan dan perkembangannya.

Dari paparan pendapat dua ahli tersebut, dapat dipahami bahwa konseling kelompok memunyai dua fungsi utama yaitu, fungsi preventif, untuk mencegah siswa melakukan suatu perilaku atau tindakan yang dapat menghambat tumbuh kembangnya dan juga fungsi kuratif yaitu, mengentaskan masalah atau menghilangkan perilaku yang dapat menghambat tumbuh kembang siswa.

Tahap-tahap konseling kelompok

Kurnanto (2013: 136) mengelompokkan tahapan konseling kelompok dalam enam tahap, yakni:

1. Tahap pembentukan

Tahap ini merupakan tahap yang menetukan terkait pemilihan anggota, jumlah anggota, setting kegiatan dan penentuan aturan-aturan yang akan disepakati anggota selama mengikuti konseling kelompok.

2. Tahap peralihan

Tahap ini ditandai dengan berbagai upaya pemimpin kelompok dalam mereduksi berbagai ketegangan yang dialami oleh anggotanya karena belum terbiasa dengan suasana kelompok yang baru terbentuk. Konselor harus dapat mereduksi ketegangan para konseli agar tahap berikutnya bisa berjalan dengan lancar.

3. Tahap kegiatan

Tahap ini merupakan inti dari proses konseling, yaitu proses yang mengarah pada penyelesaian masalah para konseli. Konselor berusaha mengatur jalannya kelompok agar tetap hidup, artinya dalam membahas masalah konseli setiap anggota dapat memberikan 
masukan maupun tanggapan terhadap masalah konseli yang masalahnya dibahas.

4. Tahap penutupan

Pada tahap ini, pemimpin kelompok mengungkapkan bahwa kegiatan akan segera diakhiri, pemimpin dan anggota kelompok mengemukakan kesan dan hasil-hasil kegiatan, membahas kegiatan lanjutan, mengemukakan pesan dan harapan.

5. Tahap mengevaluasi kelompok

Pada tahap ini, konselor berusaha mengukur sejauh mana tingkat kemajuan dan keberhasilan konseli dalam mengikuti setiap sesi dalam konseling yang telah dilakukan. Konselor juga mengevaluasi keefektivan fasilitas yang digunakan serta mengevaluasi kelemahan diri sendiri saat memimpin kelompok.

6. Tahap sesi tindak lanjut

Pada tahap ini, konselor terus berupaya memberikan bantuan kepada para konseli yang menjadi anggotanya dalam membahas suatu tema. Meskipun proses konseling telah berakhir konselor masih memiliki tanggung jawab dalam mengarahkan kemana konseli harus melangkah selanjutnya, setelah kelompok dianggap telah selesai dalam membahas satu tema tertentu sebagaimana tujuan dibentuknya kelompok.

\section{Metode Penelitian}

Penelitian ini dilaksanakan di SMK Negeri 1

Kendaripada bulan Januari sampai Februari 2019. Jenis penelitian ini adalah pra eksperimen, yaitu eksperimen yang dilakukan dengan tanpa melakukan pengendalian terhadap variabel-variael yang berpengaruh. Dalam penelitian ini yang diutamakan adalah perlakuan saja, tanpa ada kelompok kontrol (Latipun, 2015). Oleh karena itu bentuk desain pra eksperimen ini yang digunakan penelitian ini adalah one group pre test and post test design.

Subjek dalam penelitian ini adalah 8 orang siswa SMK Negeri 1 Kendari kelas XI dengan karakteristik subjek ditentukan berdasarkan hasil analisis dari angket screening. Penelitian ini menggunakan alat pengumpul data berupa angket yang disusun bersadarkan indikator kejenuhan belajar. Angket yang akan digunakan terlebih dahulu diuji coba, untuk memenuhi kriteria yang telah ditetapkan dalam penelitian ilmiah yaitu validitas dan reabilitas.

Uji validitas dan ujireliabilitas pada instrumen menggunakan bantuan program komputer Statistical Packages for Social Science
(SPSS) versi 16.0. Adapun kriteria yang digunakan untuk uji validitas adalah apabila nilai $r_{x y}>r_{\text {tabel }}$ dengan taraf signifikan sebesar $0,05 \%$ maka instrument dikatakan valid, sedangkan uji reliabilitas ini didasarkan pada ketentuan bahwa apabila nilai $r_{\text {hitung }}>r_{\text {tabel }}$ maka instrumen dikatakan reliabel. Teknik analisis data menggunakan analisis deskriptif persentase untuk mengetahui gambaran kejenuhan belajar siswa dan statistik inferensial digunakan untuk menguji hipotesis penelitian.

\section{Hasil Penelitian dan Pembahasan \\ Hasil Penelitian}

Analisis deskriptif persentase

Gambaran kejenuhan belajar siswa kelas XI

SMK Negeri 1 Kendari sebelum diberikan perlakuan (pre test) dapat terlihat pada tabel berikut:

Tabel 1

Skor Pre Test Kejenuhan Belajar Siswa

\begin{tabular}{|c|c|c|c|c|}
\hline No & Nama & Skor & $\mathbf{\%}$ & Kriteria \\
\hline 1 & RSM & 271 & $79,70 \%$ & Tinggi \\
\hline 2 & ND & 246 & $72,35 \%$ & Tinggi \\
\hline 3 & MA & 257 & $75,58 \%$ & Tinggi \\
\hline 4 & RNY & 237 & $69,79 \%$ & Tinggi \\
\hline \multicolumn{2}{|l}{ Rata-rata } & $\mathbf{2 5 2}$ & $\mathbf{7 4 , 1 1 \%}$ & Tinggi \\
\hline
\end{tabular}

Berdasarkan tabel di atas, kejenuhan belajar siswa sebelum diberikan perlakuan (pre test) termasuk dalam kategori rendah. Hal ini dapat dilihat dari rata-rata persentase motivasi belajar siswa mencapai $74,11 \%$ dari 4 orang subjek penelitian.

Sedangkan gambaran kejenuhan belajar siswa setelah diberikan perlakuan berupa layanan bimbingan kelompok dapat diketahui berdasarkan hasil analisis angket kejenuhan belajar siswa, sebagaimana yang tertera pada tabel berikut ini:

Tabel 2

Skor Post Test Kejenuhan Belajar Siswa

\begin{tabular}{|l|c|c|c|c|}
\hline No. & Nama & Skor & \% & Kriteria \\
\hline 1 & RSM & 167 & $49,11 \%$ & Rendah \\
\hline 2 & ND & 177 & $50,25 \%$ & Rendah \\
\hline 3 & MA & 169 & $49,70 \%$ & Rendah \\
\hline 4 & RNY & 157 & $46,17 \%$ & Rendah \\
\hline \multicolumn{2}{l}{ Rata-Rata } & $\mathbf{1 6 6}$ & $\mathbf{4 8 , 8 2 \%}$ & Rendah \\
\hline
\end{tabular}

Berdasarkan tabel di atas, kemandirian belajar siswa setelah diberikan perlakuan (post test) mengalami perubahan kategori dari tinggi menjadi rendah. Hal ini dapat dilihat dari rata-rata 
persentase yang diperoleh yakni sekitar $48,82 \%$ dari 4 orang subjek penelitian.

Berdasarkan hasil analisis data, maka dapat diperoleh gambaran kejenuhan belajar siswa kelas XI SMK Negeri 1 Kendari sebelum dan sesudah diberikan perlakuan. Adapun hasil analisis data tersebut dapat dilihat pada tabel berikut ini:

Tabel 3

Perbandingan Skor Pre-Test - Post-Test Siswa

\begin{tabular}{|c|c|c|c|c|c|c|}
\hline \multirow{2}{*}{$\mathbf{K h}$} & \multirow{2}{*}{ ש } & \multicolumn{2}{|c|}{$x$} & \multicolumn{2}{|c|}{$\mathbf{K}^{\prime}$} & \multirow{2}{*}{ 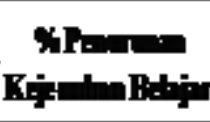 } \\
\hline & & Pnt년 & Petetet & Preted & Fottet & \\
\hline 1 & $\mathbf{Z h}$ & $7970 \%$ & $49,1 \times 6$ & Trit & Fnith & $3059 \%$ \\
\hline 2 & D & $235 \%$ & $50,20 \%$ & דים & Pinith & $2,00 \%$ \\
\hline 3 & $\mathbf{J}$ & $7,58 \%$ & 49,706 & The & Fonith & $2,58 \%$ \\
\hline 4 & R,P & $6979 \%$ & $46,17 \%$ & Trits & Plotith & 23,5\% \\
\hline \multicolumn{2}{|c|}{ B } & $\pi, \| \%$ & 5 & $\Gamma$ & Panth & $5,5 x$ \\
\hline
\end{tabular}

Dari tabel di atas diketahui bahwa sebelum diberi perlakuan (pre test) tingkat kejenuhan belajar masuk dalam kategori tinggi dengan skor persentase rata-rata $74,11 \%$. Sedangkan, setelah diberikan perlakuan (post test) tingkat kejenuhan belajar berada kategori rendah dengan skor persentase rata-rata $48,82 \%$. Hal tersebut menunjukan bahwa tingkat kejenuhan belajar siswa di SMK Negeri 1 Kendari mengalami penurunan sebesar $25,29 \%$ setelah diberikan perlakuan berupa konseling kelompok.

Analisis Statistik Inferensial

Analisis data untuk mengetahui layanan bimbingan kelompok berpengaruh dalam meningkatkan kemandirian belajar siswa kelas XI SMK 1 Negeri Kendari dilakukan analisis non parametrik dengan uji wilcoxon signed rank. Hasil perhitungan uji wilcoxon signed rank dengan menggunakan SPSS 16.00. Berdasarkan analisis statistik inferensial dengan menggunakan uji wilcoxon signed rank pada taraf signifikasi $\alpha=0,05$ diperoleh $\mathrm{P}_{\text {value }}=0,012$. Oleh karena $\mathrm{P}_{\text {value }}<\alpha(0,012<0,05)$ maka $\mathrm{H}_{0}$ ditolak. Hal ini berarti layanan bimbingan kelompok berpengaruh dalam menurunkan kejenuhan belajar siswa.

\section{Pembahasan Hasil Penelitian}

Layanan konseling kelompok dapat mengurangi kejenuhan belajar siswa, seperti yang didapat pada hasil penelitian ini bahwa kejenuhan belajar siswa kelas XI Pemasaran 3 di SMK Negeri 1 Kendari mengalami penurunan sebesar $25,29 \%$ setelah pemberian layanan konseling kelompok. Hasil penelitian ini memerkuat hasil penelitian yang dilakukan oleh Rianingsi (2016) dengan penelitian: Efektifitas Konseling Kelompok Realita Guna Mereduksi Kejenuhan Belajar Siswa MA Ummatan Wasathon Imogiri. Hasil penelitian tersebut menunjukkan bahwa konseling kelompok realita efektif untuk mereduksi kejenuhan belajar siswa MA Ummatan Wasathon Imogiri. Hal tersebut dapat dilihat dari perhitungan statistik non parametrik nilai $t_{\text {hitung }}$ lebih besar daripada $t_{\text {tabel }}$ yaitu 3,375 > 2,015. Tingkat kejenuhan belajar siswa berada pada kategori tinggi pre test sebelum diberikan perlakuan atau treatment adalah $123,40 \%$ dan setelah diberikan pelakuan atau treatment adalah 109,60\% hasil post test berada pada kategori rendah. Berarti ada perbedaan yang sangat signifikan antara pereduksian kejenuhan belajar sebelum dan sesudah diberi tindakan.

Konseling kelompok adalah salah satu metode yang dapat digunakan untuk mengurangi kejenuhan belajar siswa. Hal ini karena konseling kelompok adalah proses antar pribadi yang dinamis yang terpusat pada pemikiran dan perilaku yang disadari. Proses itu mengandung ciri-ciri terapeutik seperti pengungkapan pikiran dan perasaan sacara leluasa, orientasi pada kenyataan, pembukaan diri mengenai perasaan-perasaan mendalam yang dialami, saling percayah, saling perhatian, saling pengertian dan saling mendukung (Wibowo, 2005). Dalam konseling kelompok, berbagai permasalahan dapat di atas dengan keperdulian anggota kelompok melalui pengembangan pemahaman, sikap, keyakinan dan perilaku konseli yang tepat dengan cara memanfaatkan situasi kelompok.

Penurunan kejenuhan belajar siswa dalam penelitian ini dilakukan dengan memanfaatkan dinamika kelompok yang terjadi selama proses kelompok sehingga setiap siswa yang masalah dibahas atau anggota kelompok lainnya dapat menyadari berbagai kelemahan atau hambatan yang telah dialami. Konseling diasumsikan sebagai alat bagi siswa untuk merumuskan tujuan dan langkah yang dapat diambil oleh siswa untuk menghindari masalah yang dapat mengganggu pertumbuhan optimal.

Terjadinya penurunan kejenuhan belajar yang dialami oleh siswa dapat digunakan sebagai indikator keberhasilan treatment yang diberikan. Seperti yang telah dikemukakan oleh peneliti 
dalam hipotesis penelitian. Keberhasilan adalah proses timbal balik dari penerapan teori kelompok dan metode konseling yang dirumuskan untuk membentuk perilaku atau sikap siswa secara lebih konstruktif setelah mengikuti konseling kelompok.

Keberhasilan implementasi layanan konseling kelompok untuk mengurangi kejenuhan yang dialami oleh siswa tidak dapat dipisahkan dari antusiasme siswa dalam konseling kelompok. Semangat siswa yang muncul untuk mengikuti pelaksanaan konseling kelompok menjadi modal awal, sejauh mana aplikasi dan aplikasi berbagai keputusan dirumuskan dalam proses konseling.

Penurunan kejenuhan belajar siswa hanya dapat dicapai jika siswa benar-benar menerapkan keputusan yang telah dirumuskan selama proses konseling. Dalam penelitian ini, siswa kelas XI Pemasaran 3 SMK Negeri 1 Kendari benar-benar menerapkan berbagai keputusan yang dihasilkan dalam proses konseling. Konseling kelompok yang dilakukan peneliti mengalami lika-liku selama proses konseling kelompok atau pemberian tindakan terdapat beberapa kendala yang dihadapi oleh peneliti selama melakukan penelitian di SMK Negeri 1 Kendari di antaranya adalah keterbatasan waktu selama proses konseling, siswa yang berhalangan tidak sempat mengikuti proses konseling, konseling kelompok yang melibatkan berbagai macam karakter siswa sehingga ada beberapa siswa masih canggung di awal-awal proses konseling.

\section{Kesimpulan dan Saran \\ Kesimpulan}

Berdasarkan hasil uji coba hipotesis dengan menggunakan uji wilcoxon signed rank pada taraf signifikan $\alpha=0,05$ diperoleh $\mathrm{p}_{\text {value }}=0,012 . \mathrm{P}_{\text {value }}<$ $\alpha(0,012<0,05)$ dengan demikian $\mathrm{H}_{0}$ ditolak. Maka dapat disimpulkan bahwa layanan konseling kelompok dapat mengurangi kejenuhan belajar siswa di SMK Negeri 1 Kendari.

\section{Saran}

\section{Bagi sekolah}

Peneliti memberikan layanan bimbingan kelompok di ruangan kelas. Sehingga mengganggu siswa yang bukan bagian dari subjek penelitian karena harus meninggalkan ruang kelas. Hal tersebut disebabkan karena ruang guru BK dan staf administrasi sekolah disatukan dalam satu ruangan. Sekolah mestinya menyiapkan ruangan khusus bimbingan dan konseling yang memadai, agar pelaksanaan kegiatan bimbingan dan konseling bisa lebih efektif.

2. Bagi guru BK

Berdasarkan anlisis data angket screening yang diperoleh peneliti, masih ada beberapa siswa yang memiliki kejenuhan belajar yang rendah dan tidak termasuk dalam subjek penelitan peneliti. Sehingga perlu ditangani lebih lanjut oleh guru BK dengan menerapkan layanan konseling kelompok dalam menangani permasalahan tersebut.

3. Bagi siswa

Setelah mendapatkan treatment berupa layanan konseling kelompok terjadi penurunan yang cukup baik pada siswa. Untuk itu, siswa perlu mengaplikasikan apa yang telah diperoleh dalam kegiatan layanan bimbingan kelompok agar kejenuhan belajarnya penurunan. Dan dalam pelaksanaan layanan bimbingan dan konseling selanjutnya hendaknya serius menyikapi dengan baik apa yang diberikan oleh guru BK sehingga bisa memahami apa yang disampaikan. Begitupun saat pemberian layanan lainnya.

4. Bagi peneliti selanjutnya

Penelitian ini memberikan gambaran bahwa layanan bimbingan kelompok memiliki pengaruh dalam menurunkan kejenuhan belajar siswa, terbatas pada penggunaan angket sebagai metode pengumpulan data. Oleh karena itu, hendaknya penelitian selanjutnya diharapkan dapat mengembangkan dengan menggunakan metode yang lain untuk mengukur kejenuhan belajar siswa, misalnya dengan observasi (pengamatan).

\section{Daftar Pustaka}

Latipun. (2015). Psikologi Konseling. Malang: UMM Pers.

Lubis, N. L dan Hasnida. (2016). Konseling Kelompok. Jakarta: Kencana.

Kurnanto, Edi. (2013). Konseling Kelompok. Bandung: Penerbit Alfabeta.

Kurrniawan, Novian Gangga. (2016). Efektivitas Musik Klasik (Mozart) Untuk Menurunkan Kejenuhan Belajar Siswa Kelas XI SMAN 4 Yogyakarta. Jurnal Bimbingan Konseling. Vol 7, Nomor 5. 
Ningsih, Fitri. (2016). Efektifitas Teknik Relaksasi untuk Mengurangi Kejenuhan Belajar. EJournal Bimbingan dan Konseling. Vol 7, nomor 5 .

Prayitno dan Erman Amti. (2015). Dasar-dasar Bimbingan dan Konseling. Jakarta: Rineka Cipta.

Rianingsih. (2016). Efektivitas Konseling Kelompok Realita Guna Mereduksi Kejenuhan Belajar Siswa MA Ummatan Wsathon Imogiri. E-journal Undiksa Jurusan Bimbingan dan Konseling. Vol 2. No 1.

Setyosari, Punaji. (2013). Metode Penelitian Pendidikan \& Pengembangan Edisi Ketiga. Malang: Kencana Premedia Group.

Sugiono. (2010). Metode Penelitian Pendidikan. Jakarta: Alpabeta.

Sukardi, Dewa Ketut. (2002). Pengantar Pelaksanaan Program Bimbingan dan Konseling di Sekolah. Jakarta: PT Rineka Cipta.

Syah, Muhibbin. (2017). Psikologi Belajar. Jakarta: Rajawali Pers.

Tohirin. (2015). Bimbingan dan Konseling di Sekolah dan Madrasah. Jakarta: Rajawali Pers.

Widari, Ni Kadek., I Ketut Dharsana \& Kadek Suranata. (2014). Penerapan Teori Konseling Rasional dengan Teknik Relaksasi untuk Menurunkan Kejenuhan Belajar Siswa Kelas X MIA 2 SMA Negeri 2 Singaraja. E-Journal Undiksa Jurusan Bimbingan Konseling. Vol 2 No 1. 